\title{
Effect of FYM, PSB Inoculation and Phosphorus Levels on Growth and Developmental Stages of Blackgram
}

\author{
Ashish Sharma* and Pawan Pathania \\ Department of Agronomy, Forages and Grassland Management, CSK Himachal Pradesh \\ Krishi Vishvavidyalaya Palampur (Himachal Pradesh), India \\ *Corresponding author
}

Ke y w o r d s
FYM, PSB
inoculation,
Phosphorus and
Blackgram
Article Info
Accepted:
24August 2019
Available Online:
10 September 2019

A B S T R A C T
A field experiment was conducted during Kharif season of 2016 to study the effect of seed inoculation and phosphorus levels on the yield and quality of blackgram at the Research Farm of Research Sub Station (Berthin), Bilaspur. The experiment was laid out in a Factorial Randomized Block Design (FRBD) with three replications and total sixteen treatment combinations consisting of two levels of FYM viz., control and 10 t/ha, two levels of PSB viz., no inoculation and with inoculation and four levels of phosphorus viz., control, 20, 30 and $40 \mathrm{~kg} \mathrm{P}_{2} \mathrm{O}_{5} /$ ha. Plant height was recorded significantly highest with the application of $40 \mathrm{~kg} \mathrm{P}_{2} \mathrm{O}_{5} / \mathrm{ha}+\mathrm{FYM}$ + PSB and higher dry matter accumulation at 30,60 DAS and at harvest was recorded with the FYM applied @ 10 t/ha, whereas plant population, days taken to emergence, pod formation and physiological maturity were found non significant.

\section{Introduction}

Phosphorus is a major nutrient element in legume nutrition, as it is involved in several energy transformation and biochemical reactions including biological nitrogen fixation. Phosphorus is a structural part of the membrane system of the cell, the chloroplast and mitochondria. Phosphorus is second most critical plant nutrient but for pulses, it assumes primary importance, owing to its important role in root proliferation and thereby atmospheric nitrogen fixation. Majority of phosphorous gets fixed in the soil due to various factors. The yield and nutritional quality of pulses is greatly influenced by application of phosphorus.

Application of phosphorus along with PSB, improved phosphorus uptake by plants and yields indicating that the PSB are able to solubilize phosphates and to mobilize 
phosphorus in crop plants. The role of PSB is very important, as it helps in dephosphorylation of phosphorus bearing organic compounds. Release of phosphorus by PSB from insoluble and fixed/adsorbed forms is an important aspect regarding phosphorus availability in soils.

FYM is the decomposed mixture of dung and urine of farm animals along with litter and left over material from roughages or fodder fed to the cattle. It contains $0.5 \% \mathrm{~N}, 0.2 \% \mathrm{P}_{2} \mathrm{O}_{5}$ and $0.5 \% \mathrm{~K}_{2} \mathrm{O}$. It helps in improving soil health through its effect on amending soil physical, chemical and biological properties. FYM ensures proper aeration in soil and improves water holding capacity of the soil and helps in more efficient utilization of chemical fertilizers. For example, it helps in increasing the population of soil micro-organisms that enhances the availability of plant nutrients in the soil. It helps in improving soil organic carbon status (carbon sequestration). Hence, in the present investigation, effect of FYM, PSB inoculation and phosphorus levels on growth and developmental stages of blackgram was undertaken.

\section{Materials and Methods}

\section{Experimental site}

The experimental site was located at $31^{\circ} 41^{\prime} \mathrm{N}$ latitude, $76^{\circ} 62^{\prime} \mathrm{E}$ longitude and situated at an elevation of 661 meters above mean sea level. The site falls in the sub-mountain and low hill zone of Himachal Pradesh.

\section{Climate and weather conditions}

Agro-climatically Berthin falls under the subtropical warm sub humid zone of Himachal Pradesh. The weather data during the period of experimentation recorded at meteorological observatory of Research Farm of Research Sub Station, Berthin.
The data reveals that weekly maximum and minimum temperature ranged from 32.2 to $35.2{ }^{\circ} \mathrm{C}$ and 8.9 to $24.1{ }^{\circ} \mathrm{C}$, respectively during the growing season. The total rainfall during the cropping season was $573.3 \mathrm{~mm}$.

\section{Soil characteristics}

Before the commencement of the experiment, composite soil sample from $0-15 \mathrm{~cm}$ depth was collected from the experimental field before the sowing of the crop.

The soil sample was then air dried, ground, passed through $2 \mathrm{~mm}$ sieve and analyzed for various physico-chemical properties as per standard methods. The results of analysis have been presented in Table 1.

\section{Treatment details}

Sixteen treatment combinations [two levels of farm yard manure ( 0 and $10 \mathrm{t} / \mathrm{ha})$, two levels of phosphorus solubilizing bacteria (no inoculation and with inoculation) and four levels of phosphorus $(0,20,30$ and $40 \mathrm{~kg} / \mathrm{ha})]$ were tested in Factorial Randomized Block Design (FRBD) with three replications. The details of the treatments are given as under:

Farm Yard Manure (t/ha)

Control (without FYM)

FYM

\section{Phosphorus Solubilizing Bacteria}

No inoculation

With inoculation

\section{Phosphorus $\left(\mathrm{kg} \mathrm{P}_{2} \mathrm{O}_{5} /\right.$ ha $)$}

Control

20

30

40 


\section{Results and Discussion}

\section{Plant population}

The data pertaining to number of plants per square metre as influenced by different treatments have been presented in Table 2 and reveals that the plant population was not influenced significantly with the application of farm yard manure, PSB inoculation and phosphorus levels at the harvest stages of observations.

\section{Plant height (cm)}

The data on plant height of black gram were recorded at 30,60 DAS and at harvest as influenced by Farm Yard Manure, PSB inoculation and phosphorus levels has been given in Table 3.

An appraisal of the data indicated that plant height at 30 DAS, 60 DAS and at harvest of black gram was significantly influenced by the application of farm yard manure. Application of farm yard manures @ 10 t/ha registered significantly taller plant height at 30 DAS, 60 DAS and at harvest as compared to control. The increase in plant height might be due to addition of FYM in the soil that improved physical, chemical and biological properties of soil and this leads to improvement in the root growth and development and thereby uptake of nutrients and water from greater soil volume resulting in to better plant growth. The present findings are in close agreement with Kumar and Puri (2002), Ghanshyam et al., (2010), Jat et al., (2012) and Tomar et al., (2013).

The plant height of black gram was significantly influenced due to inoculation of PSB at 30 DAS, 60 DAS and at harvest as compared to control. More plant height was obtained due to inoculation of PSB over no inoculation.
A perusal of data presented in Table 3 indicated that the plant height was significantly influenced by application of phosphorus @ $30 \mathrm{~kg} / \mathrm{ha}$ and $40 \mathrm{~kg} / \mathrm{ha}$ as compared to control. Significantly the taller plants at 60 DAS and at harvest were recorded with the application of $40 \mathrm{~kg} \mathrm{P}_{2} \mathrm{O}_{5} / \mathrm{ha}$ as compared to control. It might be due to the fact that phosphorus increased photosynthetic activity of plant and helps to develop a more extensive root system and thus enables the plant to extract more water and nutrient from soil, resulting in better development of plant growth. The present findings are in close agreement with Meena et al.,(2006),Sharma and Rana (2006), Parmar and Thanki (2007), Thenua and Kumar (2007), Ghanshyam et al., (2010), Mahetele and Kushwaha (2011), Nawange et al., (2011), Bairwa et al.,(2012) and Tomar et al.,(2013), with respect to plant height.

\section{Dry matter accumulation $\left(\mathrm{g} / \mathrm{m}^{2}\right)$}

The data recorded on dry matter accumulation at 30 DAS, 60 DAS and at harvest of crop growth as affected by FYM, PSB inoculation and levels of phosphorus have been summarized in Table 4.

The data given in Table 4 reveals that, at 30, 60 DAS and at harvest, the dry matter accumulation was significantly influenced by application of FYM @10t/ha as compared to control. The higher dry matter accumulation at 30, 60 DAS and harvest was recorded with the FYM applied @ 10 t/ha. The dry matter accumulation with FYM application was 51.4, 260.1 and $322.8 \mathrm{~g} / \mathrm{m}^{2}$, but where no FYM was applied, the dry matter accumulation was 41.9, 228.3 and $307.4 \mathrm{~g} / \mathrm{m}^{2} @ 30,60$ DAS and at harvest stage of blackgram. A perusal of data given in Table 4 indicated that the application of phosphorus solubilizing bacteria significantly influenced dry matter accumulation at 30,60 DAS and at harvest as 
compared to control. The dry matter accumulation with the application of PSB was 49.9, 253.9 and $321.1 \mathrm{~g} / \mathrm{m}^{2}$, but where no PSB was applied, the dry matter accumulation was 43.5, 234.6 and 309.1 g/m² @ 30,60 DAS and at harvest stages of blackgram. This stimulating effect of phosphorus solubilizing bacteria in dry matter accumulation might be due to more availability of phosphorus from soil to plant, more synthesis of protein, fats and carbohydrates which resulted in higher dry matter production.

Phosphorus is known to take part in carbohydrate metabolism and it also act as energy carrier derived from the metabolism which are stored in phosphate molecules for subsequent use in growth, development and production of dry matter. Ahmed and Jha (1977), Tisdale et al., (1985) and Rooge et al., (1998) also reported that seed inoculation with PSB significantly increased the dry matter of legumes.

Application of phosphorus did exert their significant influence on dry matter accumulation by the application of phosphorus @ 20,30, $40 \mathrm{~kg} / \mathrm{ha}$ as compared to control in given Table 4. Significantly higher dry matter accumulation was in $40 \mathrm{~kg} / \mathrm{ha}$ followed by 30 $\mathrm{kg} / \mathrm{ha}$ and $20 \mathrm{~kg} / \mathrm{ha}$ over control (no application).

At early growth period (up to 30 DAS), root and leaf development was less, therefore, dry matter accumulation was also observed less. But, during grand growth period (after 30 DAS) these organs (leaf and roots) were active and therefore resulted in higher dry matter production.

The leaves of the plant are normally its main organs of photosynthesis. $\mathrm{P}$ improved the overall nutritional environment in the whole plant system and enhanced plant growth by promoting the meristematic activity and dry matter accumulation.

\section{Number of nodules per plant at flowering stage}

Data regarding the number of nodules per plant at flowering initiation as affected by different levels of Farm Yard Manure, PSB and phosphorus application are presented in Table 4.

Data pertaining to number of nodules per plant at flowering stage given in Table 4 revealed that application of farm yard manure remarkably influenced the number of nodules per plant at flowering initiation. Number of nodules at initiation of flowering were significantly increased with the FYM applied @ 10 t/ha.

The number of nodules noticed with FYM application at flowering initiation (32.7) over control (29.1) and per cent increase was to the extent of 12.37 per cent. Data further indicated that application of PSB also significantly influenced the number of nodules per plant at flowering stage. Significantly the highest number of nodules per plant at flowering initiation (31.7) was recorded as compare to control (30.1) given in Table 4 and the per cent increase was to the extent of 5.31 per cent.

A perusal of data presented in Table 4 revealed that the number of nodules per plant at flowering stage was significantly influenced by the phosphorus application. Different phosphorus levels influenced the number of nodules at the initiation of flowering of black gram.

The number of nodules per plant (32.4) was recorded significantly higher with $40 \mathrm{~kg}$ $\mathrm{P}_{2} \mathrm{O}_{5} /$ ha as compared to other phosphorus levels, but it was at par with $30 \mathrm{~kg} \mathrm{P}_{2} \mathrm{O}_{5} / \mathrm{ha}$ (31.7). At flowering initiation, $0 \mathrm{~kg} / \mathrm{ha}$ (control) and $20 \mathrm{~kg} / \mathrm{ha} \mathrm{P}_{2} \mathrm{O}_{5}$ levels were at par with each other. 
The increase in number of nodules with Phosphorous $40 \mathrm{~kg} / \mathrm{ha}$ was 10.58 per cent over the control (no P). Because of the better nutrition, the environment around the crop roots improved hence, helped in the increased number of root nodules.

Table.1 Physico-chemical properties of experimental soil $(0-15 \mathrm{~cm})$ before sowing

\begin{tabular}{|c|c|c|}
\hline Particular & Content in soil & Analytical method employed \\
\hline \multicolumn{3}{|l|}{ A. Physical properties } \\
\hline Sand $(\%)$ & 67.40 & \multirow{3}{*}{$\begin{array}{l}\text { International pipette method (Piper } \\
\text { 1966) }\end{array}$} \\
\hline Silt (\%) & 24.20 & \\
\hline Clay (\%) & 8.30 & \\
\hline $\begin{array}{l}\text { Texture } \\
\text { B. Chemical properties } \\
\text { pH } \\
\qquad \text { Organic carbon }(\mathrm{g} / \mathrm{kg})\end{array}$ & $\begin{array}{l}\text { Sandy clay loam } \\
7.5 \\
9\end{array}$ & $\begin{array}{l}\text { 1:2.5 soil water suspension (Jackson } \\
1967 \text { ) } \\
\text { Rapid titration method } \\
\text { (Walkely and Black 1934) }\end{array}$ \\
\hline $\begin{array}{l}\text { Available Nitrogen } \\
\text { (kg/ha) }\end{array}$ & 512.3 & $\begin{array}{l}\text { Alkaline permanganate method } \\
\text { (Subbiah and Asija 1956) }\end{array}$ \\
\hline $\begin{array}{l}\text { Available Phosphorus } \\
\text { (kg/ha) }\end{array}$ & 24.9 & Olsen's method (Olsen et al.1954) \\
\hline $\begin{array}{l}\text { Available Potassium } \\
\text { (kg/ha) }\end{array}$ & 216 & $\begin{array}{l}\text { Ammonium acetate extraction method } \\
\text { (AOAC 1970) }\end{array}$ \\
\hline
\end{tabular}

Table.2 Effect of FYM, PSB inoculation and phosphorus levels on plant population

\begin{tabular}{|c|c|c|c|}
\hline \multirow[t]{2}{*}{ Treatment } & \multicolumn{3}{|c|}{ Plant population $\left(\mathrm{No} / \mathrm{m}^{2}\right)$} \\
\hline & 30 DAS & 60 DAS & At harvest \\
\hline \multicolumn{4}{|l|}{ FYM (t/ha) } \\
\hline $\mathbf{0}$ & 24.9 & 25.9 & 26.0 \\
\hline 10 & 26.0 & 26.6 & 26.2 \\
\hline LSD $(\mathbf{P}=\mathbf{0 . 0 5})$ & NS & NS & NS \\
\hline \multicolumn{4}{|l|}{ PSB inoculation } \\
\hline No inoculation & 25.0 & 25.9 & 26.1 \\
\hline Inoculation & 25.9 & 26.6 & 26.1 \\
\hline LSD $(\mathbf{P}=\mathbf{0 . 0 5})$ & NS & NS & NS \\
\hline \multicolumn{4}{|c|}{ Phosphorus (kg/ha) } \\
\hline $\mathbf{0}$ & 25.3 & 25.6 & 25.8 \\
\hline 20 & 24.7 & 25.9 & 25.5 \\
\hline 30 & 25.6 & 26.8 & 26.6 \\
\hline 40 & 26.2 & 26.8 & 26.6 \\
\hline $\operatorname{LSD}(\mathbf{P}=\mathbf{0 . 0 5})$ & NS & NS & NS \\
\hline
\end{tabular}


Table.3 Effect of FYM, PSB inoculation and phosphorus levels on plant height

\begin{tabular}{|c|c|c|c|}
\hline \multirow[t]{2}{*}{ Treatment } & \multicolumn{3}{|c|}{ Plant height $(\mathbf{c m})$} \\
\hline & 30 DAS & 60 DAS & At harvest \\
\hline \multicolumn{4}{|l|}{ FYM (t/ha) } \\
\hline 0 & 24.6 & 39.9 & 44.9 \\
\hline 10 & 25.7 & 41.8 & 47.4 \\
\hline LSD (P=0.05) & 0.9 & 1.5 & 2.1 \\
\hline \multicolumn{4}{|l|}{ PSB inoculation } \\
\hline No inoculation & 24.6 & 40.0 & 45.0 \\
\hline Inoculation & 25.6 & 41.8 & 47.3 \\
\hline LSD $(P=0.05)$ & 0.9 & 1.5 & 2.1 \\
\hline \multicolumn{4}{|c|}{ Phosphorus (kg/ha) } \\
\hline $\mathbf{0}$ & 24.0 & 38.6 & 42.6 \\
\hline 20 & 24.9 & 40.7 & 46.0 \\
\hline 30 & 25.7 & 42.1 & 48.0 \\
\hline 40 & 25.9 & 42.1 & 48.0 \\
\hline LSD $(P=0.05)$ & 1.3 & 2.1 & 3.0 \\
\hline
\end{tabular}

Table.4 Effect of FYM, PSB inoculation and phosphorus levels on dry matter accumulation and nodules per plant

\begin{tabular}{|c|c|c|c|c|}
\hline \multirow[t]{2}{*}{ Treatment } & \multicolumn{3}{|c|}{ Dry matter accumulation $\left(\mathrm{g} / \mathrm{m}^{2}\right)$} & \multirow[t]{2}{*}{ Nodules/plant } \\
\hline & $30 \mathrm{DAS}$ & $60 \mathrm{DAS}$ & At harvest & \\
\hline \multicolumn{5}{|l|}{ FYM (t/ha) } \\
\hline $\mathbf{0}$ & 41.9 & 228.3 & 307.4 & 29.1 \\
\hline 10 & 51.4 & 260.1 & 322.8 & 32.7 \\
\hline $\operatorname{LSD}(P=0.05)$ & 2.0 & 11.6 & 11.9 & 1.5 \\
\hline \multicolumn{5}{|c|}{ PSB inoculation } \\
\hline No inoculation & 43.5 & 234.6 & 309.1 & 30.1 \\
\hline Inoculation & 49.9 & 253.9 & 321.1 & 31.7 \\
\hline $\operatorname{LSD}(\mathbf{P}=\mathbf{0 . 0 5})$ & 2.0 & 11.6 & 11.9 & 1.5 \\
\hline \multicolumn{5}{|c|}{ Phosphorus (kg/ha) } \\
\hline $\mathbf{0}$ & 42.2 & 221.8 & 289.3 & 29.3 \\
\hline 20 & 44.8 & 239.1 & 307.5 & 30.2 \\
\hline 30 & 47.2 & 253.7 & 327.9 & 31.7 \\
\hline 40 & 52.5 & 262.3 & 335.7 & 32.4 \\
\hline $\operatorname{LSD}(\mathbf{P}=\mathbf{0 . 0 5})$ & 1.3 & 16.4 & 16.8 & 2.1 \\
\hline
\end{tabular}


Table.5 Effect of FYM, PSB inoculation and phosphorus levels on days taken to emergence, pod formation and physiological maturity

\begin{tabular}{|c|c|c|c|}
\hline \multirow{2}{*}{ Treatments } & \multicolumn{3}{|c|}{ Days taken to } \\
\hline & Emergence & Pod formation & $\begin{array}{l}\text { Physiological } \\
\text { maturity }\end{array}$ \\
\hline \multicolumn{4}{|l|}{ FYM (t/ha) } \\
\hline $\mathbf{0}$ & 8.3 & 52.6 & 71.8 \\
\hline 10 & 8.2 & 54.6 & 73.6 \\
\hline LSD $(P=0.05)$ & NS & NS & NS \\
\hline \multicolumn{4}{|l|}{ PSB inoculation } \\
\hline No inoculation & 8.3 & 54.2 & 72.7 \\
\hline Inoculation & 8.2 & 53.0 & 72.7 \\
\hline LSD $(P=0.05)$ & NS & NS & NS \\
\hline \multicolumn{4}{|c|}{ Phosphorus (kg/ha) } \\
\hline $\mathbf{0}$ & 8.5 & 55.1 & 73.9 \\
\hline 20 & 8.2 & 54.5 & 73.3 \\
\hline 30 & 8.2 & 52.5 & 72.0 \\
\hline 40 & 8.0 & 52.3 & 71.5 \\
\hline LSD $(\mathbf{P}=0.05)$ & NS & NS & NS \\
\hline
\end{tabular}

The presence of more phosphorus was found to stimulate not only early onset of nitrogen fixation but also to longer functioning of nodules (Bonetti et al., 1984).

Phosphorus fertilization helps in promoting root growth, translocation of photosynthates and being the constituent of nucleic acid, phytin and phospholipids helps in the efficient function of nodulating bacteria. Thus expanded root growth system increased the number and dry weight of nodules.

\section{Developmental stages}

The data on different phenophases viz., number of days taken to emergence, number of days to pod formation and days taken to physiological maturity has been presented in Table 5.

A cursory look at the data revealed nonsignificant variations in different phenophases of blackgram under FYM, PSB and levels of phosphorus.

\section{References}

Ahmed, N., and Jha, KK. 1977. Effect of inoculation with phosphate solubilizing organisms on the yield and $\mathrm{P}$ uptake of gram. Journal of Indian Society of Soil Science 39: 105-106

Bairwa, RK., Nepalia, V., Balai, CM., Chauhan, GS., and Ram, B. 2012. Effect of phosphorus and sulphur on growth and yield of summer mungbean. Journal of Food Legumes 25: 211-214

Bonetti, R., Montanheiro, MNS., and Saito, MT. 1984. The effects of phosphate and soil moisture on the nodulation and growth of Phaseolus vulgaris. Journal of Agricultural Sciences Cambridge 103: 95-102

Ghanshyam, Kumar, R., and Jat, RK. 2010. 
Productivity and soil fertility as affected by organic manures and inorganic fertilizers in greengram (Vigna radiata L.) - wheat (Triticum aestivum L.) system. Indian Journal of Agronomy 55: 16-21

Jat, A., Arvadia, MK., Tandel, B., Patel, TU., and Mehta, RS. 2012. Response of saline water irrigated greengram to land configuration, fertilizers and farm yard manure in Tapi command area of South Gujarat. Indian Journal ofAgronomy 57: 270-274

Kumar, P., and Puri, UK. 2002. Response of frenchbean varieties to phosphorus and farm yard manure application. Indian Journal of Agronomy 47: 8688

Mahetele, D., Kushwaha, HS. 2011. Productivity and profitability of pigeonpea as influenced by farm yard manure, phosphorus solubilizing bacteria and phosphorus fertilization under rainfed condition. Journal of Food Legumes 24: 72-74

Meena, LR., Singh, RK., and Gautam, RC. 2006. Effect of moisture conservation practices, phosphorus levels and bacterial inoculation on growth, yield and economics of chickpea. Legume Research 29: 6872

Nawange, DD., Yadav, AS., and Singh, RV. 2011. Effect of phosphorus and sulphur application on growth, yield attributes and yield of chickpea. Legume Research 34: 48-50

Parmar, PP., and Thanki, JD. 2007. Effect of irrigation, phosphorus and biofertilizers on growth and yield of rabi greengram (Vigna radiata L.) under South Gujarat condition. Crop Research 34: 100-102

Rooge, RB., Patil, VC., and Ravikishan, P. 1998. Effect of phosphorus application with phosphate solubilizing organisms on the yield, quality and $\mathrm{P}$ uptake of soybean. Legume Research 21: 85-90

Sharma, RP., and Rana, SS. 2006. Response of rajmash varieties to phosphorus in cold arid region of Himachal Pradesh. Indian Journal of Pulses Research 19: 231-233

Thenua, OVS., and Kumar, P. 2007. Effect of intercropping, phosphorus levels and bio -fertilizers on the performance of blackgram. Annals of Agricultural Research (New Series) 28: 213-218

Tisdale, SL., Nelson, WL., and Beaton, J. 1985. Soil fertility and fertilizer IV. The Macmillian Publishing Company, New York. pp 62-66.

Tomar, TS., Kumar, S., and Tomar, S. 2013. Effects of plant density, nitrogen and phosphorus on blackgram (Vigna mungo L. hepper). Annals of Agriculturural Research (New Series) 34: 374-379

\section{How to cite this article:}

Ashish Sharma and Pawan Pathania 2019. Effect of FYM, PSB Inoculation and Phosphorus Levels on Growth and Developmental Stages of Blackgram. Int.J.Curr.Microbiol.App.Sci. 8(09): 2450-2457. doi: https://doi.org/10.20546/ijcmas.2019.809.283 